\title{
Prepaid Electricity Marketing Communication Strategy at PT. PLN (Persero) Temanggung Customer Service Unit
}

\author{
Muhammad Hasan Absori ${ }^{1 *}$ and Deni Ramdani ${ }^{2}$ \\ 1,2 Universitas Tidar, Magelang, Indonesia
}

\begin{abstract}
PT. PLN (Persero) is a provider of electrical energy services in Indonesia. Technological developments encourage the innovation of prepaid electricity programs in providing effective and efficient services to consumers. So marketing communication is one of the strategies used to introduce prepaid electricity products to the public. marketing communication is communication that is used to improve marketing strategies in expanding the target market segmentation. PT. PLN (Persero) Temanggung Customer Service Unit uses socialization techniques in delivering prepaid electricity programs to the Temanggung community. The purpose of this study was to determine the form of marketing communication channels used by PT. PLN (Persero) Temanggung Customer Service Unit to provide prepaid electricity program information to consumers in order to increase prepaid electricity usage in Temanggung. This study uses a qualitative description method. Research data obtained by interview and observation conducted at PT. PLN (Persero) Temanggung Customer Service Unit. In this study conducted with triagulation techniques. The research results of PT. PLN (Persero) Temanggung Customer Service Unit uses marketing communication channels in promoting prepaid electricity programs. The message delivered contains the difference between prepaid and postpaid electricity, benefits, token costs or electricity energy vouchers and how to purchase tokens on the prepaid electricity program.
\end{abstract}

Keywords: Marketing Communication Strategy, Prepaid Electricity

\section{Introduction}

The rapid development of increasingly sophisticated technology. Encourage the use of technology by humans every day that is useful for survival and comfort of life. Technological sophistication also helps provide goods and services needed by humans. This increases the influence of human activities in the use of technology so that actions and activities run effectively and efficiently every day. The development of technology is also used by the government in increasing the effectiveness of services to the community. Good with the optimal distribution of information and energy services to the community.

PT. PLN (Persero), which is one of the State-Owned Enterprises (BUMN) that serves and provides electricity services in Indonesia. In serving and providing electrical energy services needed by the public PT. PLN (Persero) has several service units located in various regions in Indonesia. which is useful to provide convenience and optimization of electricity services on time to customers. In practice there are two types of electrical systems, namely postpaid electricity and prepaid electricity. Postpaid electricity is an electricity service by paying the electricity load every 20th of every month. Prepaid electricity is an electricity service that spends money or costs in advance to buy tokens in order to enjoy PLN electricity services.

Prepaid electricity was created to handle customer complaints regarding surging electricity usage, incorrect meter readings, arrival of meter officers who were

* Corresponding author. Email address: muhammadhasanabsori@gmail.com 
considered annoying (Wahyuningtiyas, 2013). Also to reduce losses received by the company due to late payment by postpaid electricity customers. It is expected that using prepaid electricity can overcome these complaints, so customers can optimize electricity by setting their own monthly purchase and electricity schedule and not having to be afraid of paying late every month. This increase is also expected so that PT. PLN (Persero) continues to improve service and electricity quality to customers so that customer loyalty in using services is maintained. So some strategies are needed to achieve this.

Strategy is the overall conditional decision about the action to be taken to achieve the goal (Doembana, Rahman \& Farhan, 2017). A unified, broad and integrated plan that connects the advantages of the company's strategy that is useful in achieving company goals through proper implementation by the company (Cahyono, 2016). Marketing is one of the keys to improving approaches to help companies make sales strategies to the public. marketing strategy is very important for the company, by taking an approach that is used to help the company in achieving its goals which contain decisions about target markets, product placement, marketing mix, and the level of marketing mix required (Triyanto, 2015).

So marketing strategies are very important for a company's success in making marketing decisions that are useful for achieving company goals. The proper use of strategy is able to make the company survive in competition and increase the acquisition of the company to achieve goals. Good communication between the company and the customer is also needed to maintain the relationship between the two. Which is also useful for maintaining good relations between companies and customers expanding market segments.

Marketing communication is a form of communication in strengthening marketing strategies in obtaining broader segmentation. this study can also be said as an effort to strengthen customer loyalty to the company's products and services (Kusniadji, 2016). Trying to convey to the public, especially consumers targeted through a product that supports the company's marketing strategy (Nurdiana, 2010). The existence of communication makes a good relationship by the company to customers who need their products or services. Building a communication requires a communication strategy in product marketing (Nurficahyanti, 2015). In formulating a communication strategy it also requires clear objectives and careful calculations of the conditions and situations of the community.

The researchers wanted to know about the communication strategy used by PT. PLN (Persero) Temanggung Customer Service Unit in order to increase the number of electricity customers in the Temanggung area. Based on a research interview with the Customer Service and Administration Supervisor (PPA), there are several marketing communication strategies used to increase the use of prepaid electricity by consumers. Implement several marketing communication strategies to market prepaid electricity in the form of personal and non-personal marketing communication strategies to consumers.

Thus it is expected that customers of PT. PLN (Persero) can understand and enjoy the ease of use of prepaid electricity in their daily needs. The purpose of this study was to determine the prepaid electricity marketing communication strategy used by PT. PLN (Persero) Temanggung Customer Service Unit to its customers, in order to increase the use of prepaid electricity at Temanggung Customer Service Unit.

\section{Literature Study}

\section{Marketing strategy}

Strategy is the overall conditional decision about action to achieve an appropriate action to achieve a goal (Cahyono, 2016). According to Wibowo, Arifin and Sunarti (2015) Strategy is also a process of determining plans by top leaders who focus on 
long-term goals. Marketing strategy is the impact of the company's expectations of the impact of marketing activities on product demand in certain markets.

\section{Marketing Communication}

Marketing communication is a continuous two-way exchange of information between buyers and sellers in a market so that the marketing process runs effectively and efficiently (Kusniadji, 2016). Communication that convinces people by providing stimuli with the aim of changing the behavior of others. According to Farahdiba (2020) the purpose of marketing communication is to obtain three stages of change aimed at consumers, the three stages include: the stage of knowledge change, the stage of attitude change, and the stage of behavior change. According to Tulasi (2012) marketing communication means the process and concept of integrated products or services to be conveyed to consumers through a channel on an ongoing basis to aim at selling products or services to consumers.

1. Public relations

2. Marketing around each village

3. Information from your mouth

4. Advertising

5. Sales promotion

6. Online marketing

\section{Research Methods}

This study uses a qualitative description method. This study tries to produce descriptive data in the form of written words from the data that has been obtained. The study was conducted at PT. PLN (Persero) Temanggung Customer Service Unit. This selection uses a purposive sampling technique to obtain maximum results. The data used are perimer and secondary data. Perimer data is obtained directly by conducting interviews and observations obtained through library studies that can support research.

According to Wilantara \& Eriyanti (2019) to obtain high-quality data, in this study a data validation check was used using a triagulation technique. In the triagulation technique of source obtained is done by member checking until data saturation is achieved. The process of data analysis begins with data collection, data reduction, data presentation, and finally conclusion drawing.

\section{Results and Discussion}

\section{PT. Prepaid Electricity Program PLN (Persero)}

The prepaid electricity program is a prepaid electricity service that allows customers to control their electricity usage as needed (Markoni, 2015). According to Hermawan \& Tuti (2011) the official launch of the prepaid electricity program was in 2009 and has been socialized since 2008 . The use of prepaid electricity such as telephone reload, customers must first buy tokens or electricity pulses to enjoy electricity services. Purchases can be made through ATMs at a number of banks or through the online electricity bill counter. Electric tokens usually consist of 20 digit numbers that are input into a special KWh meter or prepaid meter (MPB). In the MPB there are a number of features that can be read by customers related to electricity usage such as information on the number of KWh meters both from the new input, already in use, being used and the amount of remaining electrical energy.

The benefits of using prepaid electricity (http://web.pln.co.id/pelanggan/listrikpintar/keuntungan-listrik-pintar) include:

1. Ease of customers in controlling electricity usage 
Customers can monitor themselves through a prepaid electronic meter which shows the number of $\mathrm{KWh}$ usage remaining which can help regulate daily electricity usage.

2. Electricity consumption can be adjusted to the budget

The flexibility of purchasing tokens can be adjusted by customers with vouchers ranging from Rp. 20,000 to $\mathrm{Rp}$. $1,000,000$, so that it is more controlled in the budget.

3. There will be no additional costs

No charge fees due to late payment of electricity made every month.

4. Privacy is more maintained

There is no recording by the meter recording officer, because prepaid electricity automatically records the customer's electricity usage.

5. Extensive token or electricity purchase network

Purchases of tokens or electricity pulses can be obtained through ATMs, online electricity payment counters, and shopping applications that support the purchase of tokens or electricity pulses.

6. Suitable for customers who have a rental house or rented room (boarding house)

As rented house owners and rented rooms do not need to worry anymore about electricity bills that are not paid by residents because prepaid electricity usage is already the responsibility of the tenant.

Marketing Communication at PT. PLN (Persero) Temanggung Customer Service Unit

PT. PLN (Persero) Temanggung Customer Service Unit in carrying out communication strategies using socialization techniques to the public. The use of appropriate marketing communication strategies can prevent companies from losing losses due to ineffective and inefficient promotional activities (Kusniadji, 2016). The transition from the use of postpaid electricity to prepaid is desired in order to reduce losses suffered by Temanggung Customer Service Unit because there are some customers who are late paying electricity every month. This makes the loss of electricity income obtained by Temanggung Customer Service Unit. The use of prepaid electricity is also able to optimize the use of electricity by consumers because electricity usage can be set according to the needs of each month.

Marketing communication strategies to convey messages, especially consumers of the existence of a product. In establishing and implementing marketing communication strategies on prepaid electricity is the authority of the marketing department. But it is also assisted by the Customer Service Unit in Temanggung Regency. The message delivered by the communicator in socializing prepaid electricity is about the difference between prepaid and postpaid electricity, benefits, to the cost of tokens or electricity energy vouchers, and how to purchase tokens. The communication channel used to pass socialization to consumers through personal and non-personal communication channels. The personal communication channel is directly personal to the customer which is carried out every day by the area manager, unit manager and supervisor.

\section{Marketing Communication Channels of PT. PLN (Persero) Temanggung Customer Service Unit}

From the results of research conducted known marketing communication channel strategies implemented by PT. PLN (Persero) Temanggung Customer Service Unit as a way of delivering information to socialize the prepaid electricity program to the community in Temanggung Regency. From the results of research that has been done (Muzajjad, 2012), the communication strategy channel used is personal and nonpersonal communication strategies. Channels of personal communication strategies carried out to customers by managers and supervisors every day. And non-personal communication channels are carried out using mass media to help disseminate prepaid electricity information to consumers through radio, newspapers and the internet. 
Marketing communication channel conducted by PT. PLN (Persero) Temanggung Customer Service Unit in socializing prepaid electricity.

1. Public relations

Building relationships with elements of the community one of them by working with elements of local government, village government, community organizations and community event sponsors. Also by connecting free electricity that is used for public lighting. With this, it is expected to maintain the relationship that has been built between PT. PLN (Persero) Temanggung Customer Service Unit with the community. 2. Mobile Marketing for Every Village

Marketing is carried out to villages that are part of PT. PLN (Persero) Temanggung which aims to facilitate providing services and information to consumers directly. The communication was carried out by conducting a socialization seminar at the village office conducted by representatives of the employees of PT. PLN (Persero) Temanggung Customer Service Unit. Also by recording the village head, in the village which is a work area to facilitate conveying and exchanging the latest information about PLN electricity services to the village and vice versa.

3. Information From Mouth To Mouth

Dissemination of communication from each customer about prepaid electricity making it easier for the socialization process to consumers who already know about prepaid electricity service information. Word of mouth information is effective for prepaid electricity distribution felt by PT. PLN (Persero) Temanggung Customer Service Unit. Because with this it facilitates communication channels received by the public about prepaid electricity programs.

4. Advertising

The advertising process carried out by PT. PLN (Persero) Temanggung Customer Service Unit became very effective. By providing advertising that is in line with the characteristics of the targeted consumers by using the influence of the mass media. The advertising program used by Temanggung Customer Service Unit uses print and electronic media. The use of print media used as advertising media is to use brochures given to consumers and use newspapers to achieve the intended target consumers. Electronic media which is usually used by Temanggung Customer Service Unit uses internet media such as websites and uses social media to facilitate the dissemination of information to consumers. Also conducting Talkshow on local radio OFA Radio in Temanggung Regency every month to be used as a medium for disseminating information to consumers. With the increasing use of information media in the network of delivering information to consumers, it is more effective to know more about prepaid electricity programs conducted by PT. PLN (Persero) Temanggung Customer Service Unit.

5. Sales promotion

The use of promotional media of PT. PLN (Persero) Temanggung Customer Service Unit utilizes facilities that are able to support the intended consumer segments. The use of media as a promotion used is by installing prepaid electricity at a low price. This is intended so that consumers are interested in switching to using prepaid electricity programs for daily activities in the use of electrical energy. Promotional programs provided by PT. PLN (Persero) Temanggung Customer Service Unit with year-end discounts on prepaid electricity installations. The promotion is able to increase prepaid electricity programs by consumers. this program can be seen directly on the website of PT. PLN (Persero) by consumers. Thus consumers can enjoy promotional programs provided by PT. PLN (Persero).

6. Online Marketing

The use of marketing media in conducting marketing communication by PT. PLN (Persero) Temanggung Customer Service Unit. By providing convenience through online media so that customers do not need to directly register themselves to the office. Customers can access directly through the website:www.pln.co.id, Via SMS Banking, Via SMS T-Cas, and Call Center 123 or 0293-491123 for PT. PLN (Persero) 
Temanggung Customer Service Unit. This makes it easier for customers to submit electricity installation registrations, so that the time spent by customers is more effective because of the ease of service provided.

The implementation of marketing communication strategy policy that has been applied is useful for the effectiveness of achieving the objectives of the prepaid electricity program by PT. PLN (Persero) Temanggung Customer Service Unit. With the ease of information on smart electricity to the public in the use of electricity as well as saving electricity usage (Wilantara \& Eriyati, 2019). The use of several communication channels must be able to be accepted by the public. Because the policy that will be accepted is also intended and the public interest itself. Which is able to increase prepaid electricity program customers. The information provided to the public contains the convenience of service, benefits, and privacy of the customer because they are not visited by officers every month.

Measuring the success of the monthly targets achieved by PT. PLN (Persero) Temanggung Customer Service Unit is a benchmark of how the public absorbs information that has been given in marketing communications. The decision to use and switch to using prepaid electricity is the effect of achieving the effectiveness of marketing communication strategies. Marketing communication is able to create reciprocal activities that will be received by consumers and affect the company. Consumer confidence about the use of products offered by the company is the right choice for consumers. so that marketing communications activities are personal and non-personal in order to influence and persuade the use of prepaid electricity services to consumers can be done to achieve the goals to be achieved by the company.

\section{Conclusion}

Based on the results of research that has been done, it can be concluded that the marketing communication strategy to increase the use of prepaid electricity by PT. PLN (Persero) Temanggung Customer Service Unit. The marketing communication strategy uses a form of communication in strengthening marketing strategies to increase the number of prepaid electricity users. because marketing communication conveys messages, especially consumers about the existence of a product. The use of prepaid electricity has advantages that can be felt by consumers such as: (1) ease of customers in controlling electricity usage, (2) electricity usage can be adjusted to the budget, (3) will not incur additional costs, (4) privacy is more maintained, (5) extensive token or electricity purchase network

PT. PLN (Persero) Temanggung Customer Service Unit uses socialization techniques to the public to deliver prepaid electricity program information to the Temanggung community. Information that contains content about the ease of service, benefits and safeguarding customer privacy. The forms of marketing communication channels used are (1) public relations, (2) mobile marketing, (3) mouth-to-mouth information, (4) advertising, (5) sales promotion, and (6) online marketing. Using several communication channels makes the dissemination of prepaid electricity programs acceptable to the public, so that the effective delivery of information can be optimally interwoven. And able to increase the growth of prepaid electricity program customers to be received.

\section{References}

Doembana, I., Rahman, A., \& Farhan, M. (2017). Buku Ajar Manajemen dan Strategi Komunikasi Pemasaran. Zahir Publishing: Yogyakarta.

Cahyono, P. (2016). Implementasi Strategi Pemasaran Dengan Menggunakan Metode SWOT Dalam Upaya Meningkatkan Penjualan Produk Jasa Asuransi 
Kecelakaan Dan Kematian Pada PT. Prudential Cabang Lamongan. Jurnal Pendidikan Ilmu Manajemen, 1(2), 129-138.

Farahdiba, D. (2020). Konsep dan Strategi Komunikasi Pemasaran: Perubahan Perilaku Konsumen Menuju Era Disrupsi. Jurnal Ilmiah Komunikasi Makna,8(1), 22-38.

Hermawan, I., \& Tuti, R. W. D. (2011). Kualitas Pelayanan Pasang Baru Listrik Prabayar Di PT. PLN (Persero) Cikande. Kajian, 22(2), 1-17.

Kusniadji, S. (2016). Strategi Komunikasi Pemasaran Dalam Kegiatan Pemasaran Produk Consumer Goods (Studi Kasus Pada PT Expand Berlian Mulia Di Semarang). Jurnal Komunikasi, 8(1), 83-98.

Markoni. (2015). Analisis Kepuasan Pelanggan PT PLN (Persero) Terhadap Proses Pemasaran Listrik Prabayar (Studi Kasus PT PLN WS2JB Rayon Sukarami). Jurnal Manajemen \& Bisnis Sriwijaya, 13(4), 487-498.

Nurdiana, T. (2010). Strategi Komunikasi Pemasaran PT. PLN Dalam Mempromosikan Listrik Prabayar (Studi Pada Bagian Pemasaran PT PLN (Persero) APJ Malang, Jawa Timur). [Thesis]. Malang: University of Muhammadiyah Malang.

Nurficahyanti, F. (2015). Model Komunikasi Pemasaran Paguyuban Batik Tulis. Jurnal Komunikasi ASPIKOM, 2(5), 304-313.

Tulasi, D. (2012). Marketing Communication and Brand Awareness. HUMANIORA, $3(1), 215-222$.

Triyanto, W. A. (2015). Algoritma K-Medoids untuk Penentuan Strategi Pemasaran Produk. Jurnal SIMETRIS, 6(1), 183-188.

Wahyuningtiyas, A. (2013). Analisis Faktor-faktor Yang Mempengaruhi Rendahnya Kepuasan Pelanggan Produk Listrik Prabayar Di Semanarang. Jurnal Sains Pemasaran Indonesia, 7(2), 188-210.

Wibowo, D. H., Arifin, Z., \& Sunarti. (2015). Analisis Strategi Pemasaran Untuk Meningkatkan Daya Saing UMKM (Studi Pada Batik Diajeng Solo). Jurnal Administrasi Bisnis (JAB), 29(1), 59-66.

Wilantara, P., \& Eriyanti, F. (2019). Efektivitas Pelaksanaan Kebijakan Meter Prabayar Pada PT. PLN Persero Wilayah Kerja ULP (Unit Layanan Pelanggan) Indarung. Ranah Research, 1(2), 162-173.

Muzajjad, A. (2012). Strategi Komunikasi Pemasaran dalam Mensosialisasikan Program Listrik Prabayar (Studi pada PT. PLN (Persero) Unit Pelanggan Kebonagung Malang). [Skripsi]. Malang: Universitas Islam Negeri Maulana Malik Ibrahim.

PT. PLN (Persero). Keuntungan Listrik Pintar. http://web.pln.co.id/pelanggan/listrikpintar/keuntungan-listrik-pintar . Retrieved May 3, 2020. 